\title{
PROTEINURIA IN KIDNEY TRANSPLANT RECIPIENTS
}

\section{HABIBUR RAHMAN ${ }^{1}$, TOHID MOHAMMAD SAIFUL HOSSAIN ${ }^{1}$, AKM KHURSHIDUL ALAM ${ }^{1}$, SHAHIDUL ISLAM SELIM ${ }^{2}$, NILIMA BARMAN ${ }^{3}$, AZM MAHFUZUR RAHMAN $^{4}$, DEBATOSH PAUL ${ }^{5}$}

${ }^{1}$ Department of Urology, Bangabandhu Sheikh Mujib Medical University (BSMMU), Dhaka, ${ }^{2}$ Department of Nephrology, Bangabandhu Sheikh Mujib Medical University (BSMMU), Dhaka, ${ }^{3}$ Department of Pathology, Dr. Sirajul Islam Medical College, Dhaka. ${ }^{4}$ Department of Surgery, Dhaka Medical College, Dhaka, ${ }^{5}$ Department of Clinical Pathology, Bangabandhu Sheikh Mujib Medical University (BSMMU), Dhaka.

\begin{abstract}
Objectives: Proteinurea is one of the major causes of early graft rejection and high degree mortality in renal transplant patients. Our objective was to assess risk in post transplant patient for proteinurea and it's appropriate management.

Methods: This cross sectional study includes fifty adult kidney allograft recipients, transplanted in kidney transplant unit of Urology Department, Bangabandhu Sheikh Mujib Medical University in the period of January 2012 to December 2012.

Results: In our series, proteinuria was detected in $44 \%$ of the renal transplant recipients in variant amount. In this study the male and female ratio was 7:3. There was a highly significant level of proteinuria in proteinuric group than that of non-proteinuric group [538.09 (313.36) $\mathrm{mg} / 24 \mathrm{hr}$ vs. 44.48 (23.39) $\mathrm{mg} / 24 \mathrm{hr}$; $p$ value $<0.0001]$. Acute rejection and death was found in $22 \%$ and $8 \%$ recipients respectively, which were more observed in proteinuric group.
\end{abstract}

Conclusion: Based on these data, proteinuria should be monitored periodically at posttransplant period and investigation of the cause should be pursued vigorously.

Key wards: Proteinuria; Kidney Transplant recipient; Acute rejection.

Bangladesh J. Urol. 2014; 17(2): 61-63

\section{Introduction}

Proteinuria is a sensitive marker of renal dysfunction. Accounting proteinuria in renal transplant recipients is found to be a significant risk factor of graft failure as well as mortality in several studies [1-3]. It is also associated with cardiovascular disease events[4]. Meanwhile, the prevalence of proteinuria at $1^{\text {st }}$ year after renal transplantation ranges between $11 \%-45 \% 9$ [3-9]. It is frequently seen immediately after transplantation, may be as a consequence of the ischemia-reperfusion injury [10]. In a study found that new onset proteinuria occurred from glomerulonephritis, systemic disease, or arterial hypertension as original disease [6]. However, the causes of persistent proteinuria have been attributed to

Correspondence: Md. Habibur Rahman, Department of Urology, Bangabandhu Sheikh Mujib Medical University (BSMMU), Dhaka, Email: dulaluro@yahoo.com. recurrent or de novo glomerulonephritis, allograft glomerulopathy, chronic rejection, nephrosclerosis, renal vein thrombosis and reflux nephropathy $[11,12]$.

The negative influence of proteinuria on graft survival is independent of other concomitant factors such as renal function or the etiology of the complication[7,8]. For this reason, the presence of proteinuria must be monitored periodically investigated in all kidney transplant recipients[13]. The purpose of the present study was to investigate the status of proteinuria in renal transplant recipients with its associated factors.

\section{Materials and Methods}

This cross sectional study includes all adult kidney allograft recipients, transplanted in kidney transplant unit of Urology Department, Bangabandhu Sheikh Mujib Medical University between September 2011 and August 
2012. The patients received kidney transplant because of end stage renal failure due to chronic glomerulonephritis, pyelonepritis, diabetes and various other nephropathies. Among all adult patients, we selected 50 patients who were followed up at posttransplant period in two stages at 6th week and 18th week. Here in results, we mostly encountered the 18th week follow up outcome. Proteinuria was considered as more than $150 \mathrm{mg} / 24 \mathrm{hr}$ which was categorized as mild (150-500mg/24hr), moderate (500-1000mg/24hr) and markedly high (>1000 mg/24hr) ${ }^{3}$. Moreover, taking into account other associated factors like recipient's age and sex, donor's age and sex, serum creatinine, $\mathrm{Hb} \%$, the outcome and so on. In these analyses, patients were excluded if they had no surveillance follow up, no urine collection or both.

The data were analyzed through SPSS version 21.00. For all continuous data normality assumption were done by Shapiro Wilk test. The mean and standard deviation (SD) were calculated for continuous variables where frequency and percentage for categorical variables. Independent samples t-test was applied on continuous variables, while chi-square test was applied to determine the statistical differences between categorical variables. $P$-value $<0.05$ was considered statistically significant. The tests were applied at 95\% confidence interval.

\section{Results}

Out of fifty kidney transplant recipients, the prevalence of developing proteinuria was $42 \%(95 \% \mathrm{Cl}, 28.3 \%$ $55.7 \%$ ). In this study male was predominant over female with a ratio of $7: 3$.

Table-I

Distribution of the patients based on proteinurea

\begin{tabular}{lccc}
\hline $\begin{array}{l}\text { Urine Protein } \\
(\mathrm{mg} / 24 \mathrm{hr})\end{array}$ & $\begin{array}{c}\text { Non- proteinuric } \\
\text { patients }\end{array}$ & $\begin{array}{c}\text { Proteinuric } \\
\text { patients }\end{array}$ & $\begin{array}{c}\mathrm{P} \\
\text { value }\end{array}$ \\
\hline $\mathrm{N}^{1}$ & $29(58)$ & $21(42)$ & \\
Mean (sd) & $44.48(23.39)$ & $538.09(313.36)$ & $<0.0001^{2}$ \\
Range & $10-80$ & $160-1040$ & \\
\hline
\end{tabular}

${ }^{1} \mathrm{~N}$-Value represents number of patients and percentage of all of the patients in the parenthesis.

${ }^{2} p$-value was derived from independent sample t-test and a p value $<0.05$ was considered statistically significant $\mathrm{sd}=$ Standard Deviation
Table-II

Demographic and clinical profile of the patients

\begin{tabular}{lccc}
\hline Variable & $\begin{array}{c}\text { Non- proteinuric } \\
\text { patients }(n=29)\end{array}$ & $\begin{array}{c}\text { Proteinuric } \\
\text { patients }(n=21)\end{array}$ & $\begin{array}{c}P \\
\text { value }^{1}\end{array}$ \\
\hline Recipient's age (yr) & $45.52(5.37)^{\star}$ & $49.57(5.26)$ & $0.011^{\mathrm{s}}$ \\
$\begin{array}{l}\text { Donor's age (yr) } \\
\text { Recipient's gender }\end{array}$ & $39.45(3.42)^{*}$ & $40.00(3.54)$ & 0.581 \\
$\quad$ Male & $21(72.4) \#$ & $14(66.7)$ & 0.662 \\
$\quad$ Female & $8(27.6)$ & $7(33.3)$ & \\
$\begin{array}{l}\text { Primary renal Diagnosis } \\
\quad \text { Glomerular disease }\end{array}$ & $11(61.1) \#$ & $10(52.6)$ & 0.603 \\
$\quad$ Systemic disease & $7(38.9)$ & $9(47.4)$ & \\
$\begin{array}{l}\text { Acute rejection } \\
\quad \text { Yes }\end{array}$ & $5(17.2) \#$ & $6(28.6)$ & 0.340 \\
$\quad$ No & $24(82.8)$ & $15(71.4)$ & \\
Death & & & \\
$\quad$ Yes & $1(3.4) \#$ & $3(14.3)$ & 0.163 \\
$\quad$ No & $28(96.6)$ & 18 & $(85.7)$ \\
\hline
\end{tabular}

${ }^{1}$ chi-square test was done to detect p-value except (2) that is derived from independent sample t test. A $p$ value less than $5 \%$ was considered as statistically significant

\#Figure within parenthesis denoted corresponding column percentage

${ }^{*}$ mean (sd); S=significant

In proteinuric group, male was $66.7 \%$, whether that of $72.4 \%$ in non-proteinuric group. There was a highly significant mean (SD) level of proteinuria in proteinuric group than that of non-proteinuric group [538.09 (313.36) vs. 44.48 (23.39) $\mathrm{mg} / 24 \mathrm{hr}$; p value $<0.0001]$. Considering level of proteinuria in this group, recipients were distributed as mild, moderate and markedly high proteinuria [52.4\% vs. $33.3 \%$ vs. $14.3 \%)]$. The increasing age was found to be an associated factor to develop proteinuria. The mean (sd) age of recipients were 49.57 (5.26) and 45.52 (5.37) in proteinuric and non- proteinuric patients respectively. Acute rejection was observed in $22 \%$ recipients. Death of recipients was non-significantly excess in proteinuric group than non-proteinuric group $(14.3 \%$ vs. $3.4 \%$, p-value $=0.163)$.

\section{Discussion}

Now-a-days proteinuria is not only a sensitive marker of renal disease but also it is being recognized as an independent mediator of progression via various mechanisms, including direct mesangial toxicity, tubular overload or induction of a proinflammatory state in the kidney allograft recipient[3,14-15].

In our analysis, proteinuria was detected in $44 \%$ of the renal transplant recipients, an incidence that was similar to that in other literature $[4,6,8]$. The similar result was found in a study by Amer et al [8], the incidence of proteinuria was $45 \%$. 
Age was being a factor in developing proteinuria. In this series, mean (SD) age of the proteinuric group was more than that of non-proteinuric group. Sancho et al ${ }^{9}$ also found 50(13.8) years age in proteinuric group and 49.3(12.3) years in non-proteinuric group.

Acute rejection of renal transplantation was observed in 11 recipients. A study done by Amer et $\mathrm{al}^{8}$ also found acute rejection in 117 patients out of 613 which representing $19.08 \%$ of recipients and this result is comparable with our findings. Out of all recipients, 4 were facing to death and majority of them (3) developed in proteinuric group of our study.

\section{Conclusion}

Based on the above data, it seems logical to focus on renal transplant recipients with proteinuria who should be considered as high risk groups and management should be taken accordingly. Further cohort studies are recommended to establish this factor.

\section{Acknowledgement:}

We acknowledge Ministry of Science and Technology, Government of Peoples Republic of Bangladesh for their financial assistance to conduct this study.

Conflict of interest : None declared

\section{References}

1. Palmer BF. Proteinuria as a therapeutic target in patients with chronic kidney disease. Am J Nephrol 2007; 27: 287-93

2. First MR, Vaidya PN, Maryniak RK, Weiss MA, Munda R, Fidler JP, Penn I, Alexander JW: Proteinuria following transplantation. Correlation with histopathology and outcome. Transplantation 1984; 38: 607-12.

3. Fernandez-Fresnedo G, Plaza JJ, SanchezPlumed J, et al. Proteinuria: a new marker of long term graft and patient survival in kidney transplantation. Nephrol Dial Transplant. 2004; 19 (suppl 3): iii 47-iii51

4. Fernandez-Fresnedo G, Rodrigo E, Escallada R et al. The risk of cardiovascular disease associated with proteinuria in renal transplant patients. Transplantation 2002; 73: 1345-48.
5. Yildiz A, Erkoc R, Server MS, et al. The prognostic importance of severity and type of post-transplant proteinuria. Clin Transplant 1999; 13: 241-45

6. Roodnat JI, Mulder PG, Rischen-Vos $\mathrm{J}$ et al. Proteinuria after renal transplantation affects not only graft survival but also patient survival. Transplantation 2001; 72: 438-44.

7. Halimi JM, Laouad I, Buchler M, AI-Najjar A, Chatelet V, Houssaini TS, Nivet $\mathrm{H}$, Lebranchu Y: Early low-grade proteinuria: causes, short-term evolution and long-term consequences in renal transplantation. Am J Transplant 2005; 5: 2281-88.

8. Amer H, Fidler ME, Myslak M, Morales P, Kremers WK, Larson TS, Stegall MD, Cosio FG: Proteinuria after kidney transplantation, relationship to allograft histology and survival. Am J Transplant 2007; 7 : 2748-2756.

9. Sancho A, Gavelo E, Avila A, et al. Risk factors and prognosis for proteinuria in renal transplant recipients. Tansplant Proc 2007; 7: 2145-47.

10. Artz MA, Dooper PM, Meuleman EJ, van der Vliet JA, Wetzels JF. Time course of proteinuria after living-donor kidney transplantation. Transplantation 2003; 76: 421-23.

11. Peddi VR, Dean DE, Hariharam S, Caballo T, Schroeder TJ, First MR. Proteinuria following renal transplantation: correlation with histopathology and outcome. Transplant Proc 1997; 29: 101-103.

12. Vathsala A, Varani PN, Maryniak RK, et al. Proteinuria in cyclosporine-treated renal transplant recipients. Transjplantation 1990; 49: 35-41

13. KDIZO clinical practice guideline for the care of kidney transplant recipients. Am J Transplant 2009; 7: 2748-56.

14. Ojo AO: Cardiovascular complications after renal transplantation and their prevention. Transplantation 2006; 82: 603-610.

15. Arias M, Fernandez-Fresnedo G, Rodrigo E, et al. Non-immunologiv intervention in chronic allograft nephropathy. Kidney Int 2005;68 (suppl 99): s118-24. 